13. Україна: дорожня карта розвитку галузей виробництва одягу та взуття. J.E. Austin Associates. 2017. URL: https://ukrlegprom.org/files/ukrlegprom-roadmap.pdf (дата звернення 10.04.2020)

\title{
References:
}

1. Miroshnichenko, O.A., \& Nelina, N.G., \& Felenyuk, O.V. (2017) Clothing exports to the EU. Guide for Ukrainian entrepreneurs. Kyiv. 116 p. URL: https://ukrlegprom.org/en/export/eksport-odiahu-do-ies-hid-dlia-ukrainskykh-pidpryiemtsiv/ [in Ukrainian].

2. Boyko, V.S., \& Tarasova, K.I. (2019) Analysis of the development of light industry in Ukraine. Statistics - a tool for socioeconomic research: a collection of scientific student papers. Vol. 5. pp. 52-62. URL: http://dspace.oneu.edu.ua/jspui/bitstream/123456789/9328/1/\%D0\%90\%D0\%BD\%D0\%B0\%D0\%BB\%D1\%96\%D0\%B7\%20 \% D1\% 80\% D0\% BE\% D0\% B7\% D0\% B2\% D0\% B8\% D1\% 82\% D0\% BA\% D1\% 83\% 20\% D0\% BB\% D0\% B5\% D0\% B3\% D0\% BA \% D0\% BE\% D1\% 97\% 20\% D0\% BF\% D1\% 80\% D0\% BE\% D0\% BC\% D0\% B8\% D1\% 81\% D0\% BB\% D0\% BE\% D0\% B2\% D0\% BE \% D1\% 81\% D1\% 82\% D1\% 96\% 20\% D0\% A3\% D0\% BA\% D1\% 80\% D0\% B0\% D1\% 97\% D0\% BD\% D0\% B8.pdf [in Ukrainian].

3. Development of industry to ensure the growth and renewal of the Ukrainian economy: a scientific and analytical report / ed. Dr. Econ. Science Deineko L. NAS of Ukraine, SI "Inst. Of Economics. and predicted. NAS of Ukraine". Kyiv, 2018. 158 p. [in Ukrainian]. 4. Gavrilenko T., \& Brodyuk I. (2018) Prospects for the development of light industry in Ukraine in an unstable environment. Economic horizons. No 1 (4). pp. 28-34. URL: http://eh.udpu.edu.ua/article/view/002834/128214 [in Ukrainian]

5. Analytical materials of light industry. 2019. URL: https://ukrlegprom.org/ua/analytics/ [in Ukrainian].

6. Commodity structure

of foreign trade in

2019. http://ukrstat.gov.ua/operativ/operativ2019/zd/tsztt/tsztt_u/arh_tsztt2019_u.html/ [in Ukrainian]. trade in certain types of goods by
country.
2019
URL: http://ukrstat.gov.ua/operativ/operativ2020/zd/e_iovt/arh_iovt2020.htm [in Ukrainian].

8. Commodity structure of retail trade turnover of enterprises of retail trade in light industry goods. 2019. URL: http://www.ukrstat.gov.ua/operativ/operativ2018/sr/tsrtp/tsrtp2017_u.htm [in Ukrainian].

9. Indices of physical volume of retail trade turnover of retail trade enterprises by product groups in 2019. 2019. URL: http://www.ukrstat.gov.ua/operativ/operativ2018/sr/ind_fiz_obs_poz_tovar/arch_ind_fiz_obs_poz_tovar_u.htm [in Ukrainian].

10. Structure of wholesale trade turnover of wholesale trade enterprises by types of economic activity in 2018-2019 URL: http://www.ukrstat.gov.ua/operativ/operativ2007/sr/sot/sot_u/sot_rik_u.htm [in Ukrainian].

11. The Ministry of Social Policy wants to settle the "second-hand", which comes under the guise of a "humanitarian". 2019. URL: https://www. althoughda.com.ua/news/2019/12/3/654417/ [in Ukrainian].

12. Ukrainian manufacturers of footwear and clothing on the Canadian market. 2019. URL: https://ukrlegprom.org/en/export/ukrainski-vyrobnyky-vzuttia-ta-odiahu-na-kanadskomu-rynku/ [in Ukrainian].

13. Ukraine: a roadmap for the development of clothing and footwear industries. J.E. Austin Associates. 2017. URL: https://ukrlegprom.org/files/ukrlegprom-roadmap.pdf [in Ukrainian].

Дата подання публікації 28.03.2020 р.

УДК 338.24:332

Прус Ю.І., викладач кафедри управління та адміністрування Prus Yu., lecturer of Department of Management and Administration https://orcid.org/0000-0003-0320-0131

\section{КОНЦЕПТУАЛЬНИЙ ПЫЛХІ ДО УПРАВЛІННЯ РОЗВИТКОМ ПРОСТОРОВОГО КАПІТАЛУ}

\author{
Харківський національний університет імені В.Н. Каразіна
}

Статтю присвячено обгрунтуванню концептуального підходу до управління розвитком просторового капіталу, оскільки в умовах сьогодення недостатньо ефективним $є$ застосування стандартних прийомів та інструментів менеджменту при досягненні сталості економічного розвитку. Аналізуючи, систематизуючи та узагальнюючи наукові праці іноземних та вітчизняних дослідників, розглянуто еволюцію концепцій капіталу та простору, запропоновано авторське визначення поняття «просторовий капітал».

Розглянуто альтернативні моделі обгрунтування нерівномірності економічного простору (центрально-периферійна модель, модель чинників «першої» та «другої» природи). Узагальнено показники та методи кількісної оцінки нерівномірності розвитку просторового капіталу, серед яких найбільш прийнятними є індекси Тейла, індекс Аткінсона. Вони дозволяють виявити масштаб, динаміку та структуру нерівномірності розвитку просторового капіталу за кожною компонентою. Запропоновано п’ять груп показників оцінки якості просторового капіталу індустріальних центрів як основних осередків його розвитку, генераторів та ретрансляторів глобальних змін. Доцільність використання структурних показників обгрунтована успішністю реалізації стратегічного плану розвитку Свропейського Союзу «Європа-2020» на засадах соціальної згуртованості та смарт спеціалізації. 
Перспективами подальших досліджень у даному напрямі є розробка практичних рекомендацій щодо удосконалення просторово-економічної політики України.

Ключові слова: нерівномірність простору, просторовий капітал, територіальний капітал, структурна подібність простору.

\title{
CONCEPTUAL APPROACH TO THE MANAGEMENT OF SPATIAL CAPITAL DEVELOPMENT
}

\author{
V.N. Karazin Kharkiv National University
}

\begin{abstract}
The article was devoted to substantiation of the conceptual approach to the management of spatial capital development, because nowadays it is not efficient enough to use standard techniques and management tools in achieving the sustainability of economic development. Analyzing, systematizing and generalizing scientific works of foreign and Ukrainian researchers, the evolution of concepts of capital and space was considered, the author's definition of the concept of "spatial capital" was proposed

Alternative models of substantiation of unevenness of economic space (central-peripheral model, model of factors of "first" and "second" nature) were considered. Indicators and methods of quantitative assessment of unevenness of spatial capital development were summarized, among which the most favorable are the Taylor indices, the Atkinson index. They allow to identify the scale, dynamics and structure of uneven development of spatial capital for each component. Five groups of indices of quality assessment of the spatial capital of industrial centers as the main centers of its development, generators and repeaters of global change were proposed. The expediency of using structural indicators was substantiated by the successful implementation of the EU-2020 Strategic Plan for the development of the European Union on the basis of social cohesion and smart specialization.

Prospects for further research in this area are the preparation of practical recommendations for improving the spatial and economic policy of Ukraine.
\end{abstract}

Key words: unevenness of space, spatial capital, territorial capital, structural similarity of space.

Постановка проблеми у загальному вигляді i ï̈ зв'язок 3 важливими науковими та практичними завданнями. У сучасних умовах інститути забезпечення стійкого економічного розвитку стикаються з новими викликами, на які не дають відповіді традиційні управлінські підходи. Викликами, які визначають недостатню ефективність класичних економічних моделей є глобалізація та інтернаціоналізація економічних відносин, прискорена діджиталізація, зменшення ролі державних політик. Водночас присутні центробіжні тенденції, посилення ролі локальних територіальних утворень, розповсюдження локалізованих (децентралізованих) моделей управління. Для інтегрального уособлення комплексу взаємодій, що зумовлюють перманентність процесів економічного розвитку широкого вжитку отримала категорія капіталу, що у розширеному трактуванні змісту охоплює сукупність чинників, поєднання яких характеризує певний вимір цінності та $є$ визначальним для розвитку окремих сфер.

У таких умовах особливо гострим питанням для України постає підвищення ефективності управління розвитком просторового капіталу. За підрахунками Світового банку [1] тільки через неефективність управління просторовим капіталом Україна втрачає щорічно 2-3\% ВВП. Враховуючи нові геоекономічні реалії, у яких формується просторовий капітал України, найближчим часом необхідно чітко визначити параметри нової просторово-економічної політики, оскільки зволікання у вирішенні цього питання загрожує опиниться Україні серед неконкурентоспроможних держав із залежною економікою й обмеженим суверенітетом.

Аналіз останніх досліджень, у яких започатковано вирішення проблеми. Значну увагу вивченню питань, що стосуються сутності феноменів просторового капіталу та просторового розвитку, приділяють іноземні науковці (зокрема, А. Аткінсон, Д. Коморницький, П. Кругман, Р. Капелло, А. Піке, 3. Пшигордзький, Г. Тейл та інші), роботи яких є надійним підгрунтям у вирішені теоретичних проблем і практичних завдань у сфері управління розвитком просторового капіталу. Теоретико-методичні засади сучасних просторових трансформацій економіки та підходи до управління цими процесами стали предметом змістовних наукових розвідок таких вітчизняних 
дослідників, як О. Батанов, А. Гриценко, І. Сгоров, К. Мезенцев, М. Мельник, Я. Олійник, В. Родченко, Л. Шевчук та інші.

Вказані праці містять ряд цінних і важливих думок як загального, так і часткового характеру, однак їх наявність не виключає подальшого вивчення проблеми, оскільки не усі питання висвітлені в достатній мірі та не з усіма твердженнями можна повністю погодитися.

Цілі статті. Мета статті полягає в обгрунтуванні концептуального підходу до управління розвитком просторового капіталу.

Виклад основного матеріалу дослідження 3 повним обгрунтуванням отриманих наукових результатів. В економіці капітал традиційно визначається як накопичення матеріальних активів, які у сукупності з землею і робочою силою становлять засоби виробництва та виступають джерелами створення доданої вартості [2]. Поняття капіталу поступово розширюється і на сьогоднішній день використовується щодо визначення різних видів ресурсів, таких як людський капітал, соціальний капітал, культурний капітал, інтелектуальний капітал, реляційний капітал, публічний капітал, природний капітал та креативний капітал.

Сучасні інтерпретації простору та території також вказують на те, що значення цих понять з часом еволюціонувало [3]. У класичній економічній теорії простір трактувався як вторинний чинник виробництва, а його значення визначалось насамперед 3 точки зору вартості розташування та відстані [4]. В умовах сьогодення простір виступає одним з ключових чинників розвитку [5], а не лише місцем, де відбуваються різноманітні соціальні процеси [6]. Серед численних концепцій, які досліджують вплив простору на забезпечення процесів розвитку, його роль особливо акцентується в ендогенних теоріях розвитку: неомаршальській (статичний вплив агломерацій) та неошумпетерській (вплив концентрації економічної діяльності на інноваційний розвиток) [7].

Серед визначень капіталу найбільш релевантним до просторового розподілу економічної активності $є$ поняття територіального капіталу, яке було введене Організацією економічного співробітництва та розвитку у 2001 році 3 метою виокремлення ресурсів території, які складають ії конкурентний потенціал [8]. Експерти OECP [9] наголошують на тому, що територіальний капітал приносить більший прибуток для певних видів інвестицій, ніж для інших, оскільки вони ефективніше використовують активи та потенціал певної території. Це означає, що території мають не лише порівняльні переваги Рікарда (тобто вони є більш конкурентоспроможними через відносні витрати чинників виробництва), але й абсолютні переваги, оскільки володіють унікальними ресурсами.

Економічний простір $\epsilon$ неоднорідним через те, що економічна діяльність концентрується у певних місцях, які мають конкурентні переваги, та обумовлює процеси перетікання людей та капіталу з одних територій та зосередження їх на інших територіях. Наслідком дії сил тяжіння місць локалізації економічної діяльності $\epsilon$ динамічний випереджаючий розвиток окремих територій та уповільнення розвитку інших просторів. Нерівномірність територіального розвитку проявляється, в першу чергу, у диспаритеті рівня розвитку просторового капіталу.

Існують альтернативні моделі обгрунтування нерівномірності економічного простору:

1. Центрально-периферійна модель, у якій центральні міста притягують до себе людські, природні, фінансові ресурси зі своєї периферії [10]. Завдяки цьому виникає можливість інноваційного розвитку центру, згодом інновації торкнуться і периферії, але зі значним часовим лагом. Міста у цій моделі $\epsilon$ ключовими драйверами перерозподілу модернізації на периферію [11]. Така модель характерна як для великих світових агломерацій, так і для регіональних і місцевих центрів.

2. Друга модель просторового розвитку виникла у рамках «нової економічної географії». Вона вбачає причиною розвитку економічної нерівномірності процес зосередження економічної діяльності на тих територіях, які володіють порівняльними 
перевагами. Так, П. Кругман [12], у якості таких переваг виділяв чинники «першої» природи (забезпеченість природними ресурсами, вигідне географічне розташування), які мало залежать від людини та чинники «другої» природи (агломераційний ефект та висока густота населення, розвинута інфраструктура, людський капітал, інституції, які впливають на підприємницький клімат тощо), що більшою мірою пов'язані 3 діяльністю суспільства та держави.

Однак вищеперераховані ресурси не $є$ сталими. Вважається, що чинники «першої» природи, які практично не залежать від людини, характерні для індустріального суспільства; для постіндустріального суспільства найбільше значення набувають чинники «другої» природи, оскільки саме вони відіграють суттєву роль у модернізації суспільства, у той час як надмірне використання ресурсних переваг уповільнює територіальний розвиток.

Інтеграція викликів процесам економічного розвитку за рахунок чинників глобалізації та децентралізації зумовлює необхідність врахування взаємодії мережевих та просторових складових та їх впливу на процеси соціально-економічного розвитку. Це дає змогу запропонувати у якості інтегральної досліджуваної категорії поняття просторового капіталу. На рис. 1 запропоновано логіку побудови категорії просторового капіталу.

Визначаючі просторову складову категорії, слід розуміти різноманіття характеристик, що можуть розглядатися: економічну, соціальну, політичну, національну, інноваційну, інформаційну та інші. Таким чином, просторова компонента може визначатися рядом категорій «економічний простір», «соціальний простір» і т.п.

Крім того, нерівномірність розвитку просторового капіталу може розглядатися у кількох вимірах: глобальному, національному та субнаціональному. Дослідження на глобальному рівні вивчають просторові нерівності між країнами у різних регіонах світу. На національному та субнаціональному рівнях проводяться дослідження диференціації розвитку між адміністративно-територіальними одиницями однієї країни або у межах iї окремих територій. Подолання диспропорцій розвитку просторового капіталу в Україні та їі регіонах є однієї з ключових цілей державної регіональної політики, яка базується на моніторингу масштабів, структури та динаміки економічних та соціальних міжтериторіальних диференціацій.

\begin{tabular}{|c|c|c|}
\hline Капітал & Територія & Простір \\
\hline $\begin{array}{c}\text { засіб створення багатства, } \\
\text { доданої вартості, } \\
\text { забезпечення } \\
\text { перманентного розвитку }\end{array}$ & $\begin{array}{c}\text { обмежена частина земної поверхні } з \\
\text { природними й антропогенними } \\
\text { властивостями, яка характеризується } \\
\text { протяжністю (площею) як особливим } \\
\text { видом просторового ресурсу, } \\
\text { географічним положенням, } \\
\text { господарською освоєністю, } \\
\text { транспортною доступністю і т.п. }\end{array}$ & $\begin{array}{c}\text { об’єднана спільними інтересами } \\
\text { сукупність об’єктів та суб’єктів } \\
\text { господарювання певної території, } \\
\text { взаємодія і просторова організація } \\
\text { яких спрямовується (через систему } \\
\text { відносин та відповідні механізми) } \\
\text { на вирішення завдань соціально- } \\
\text { економічного розвитку }\end{array}$ \\
\hline
\end{tabular}

Рис. 1. Логіка побудови категорії просторовий капітал

Джерело: розроблено автором

Важливим методичним аспектом оцінки просторового капіталу є визначення критеріальних засад його виміру. Одиницею просторового капіталу, на нашу думку, можна визначити частину території субрегіонального рівня, яка відповідає низовій адміністративній одиниці та $є$ просторовою основою для організації і діяльності органу влади або інституційного округу; проживання та працевлаштування постійних 
мешканців [13], які безпосередньо або через сформовані ними муніципальні структури вирішують питання місцевого значення, мають спільну комунальну власність, володіють на даній території нерухомим майном, сплачують комунальні податки та пов'язані індивідуальними територіальними зв'язками системного характеру.

Існує широкий доробок підходів науковців до методів оцінки нерівності розвитку просторового капіталу. Їх систематизація за критеріями: масштабу, структури та динаміки нерівності наведена у табл. 1.

У всіх трьох групах показників нерівності (табл. 1) знаходяться індекси Тейла [17] та індекс Аткінсона [18], які дозволяють виявити масштаб, динаміку та структуру нерівності за індикатором, що досліджується. Інші показники нерівності менш інформативні, хоча й переважають у роботах багатьох дослідників за даною проблематикою. Вітчизняні дослідники, як правило, обмежуються простими вимірами нерівності, такими як середнє квадратичне відхилення, коефіцієнт варіації, коефіцієнт варіації Уӥльямсона [19], коефіцієнт варіації Клоцвога-Магомедова [20], коефіцієнт фондів, децильний коефіцієнт, індекс Джині. Більшість із вказаних показників (за виключенням коефіцієнтів варіації Уїльямсона та Клоцвога-Магомедова, індексу Джині) не дозволяють враховувати такий важливий чинник як чисельність населення просторової системи, залежать від одиниць вимірювання індикатора, що досліджується, та не відповідають п'яти аксіомам нерівності: незалежність від шкали вимірювання, незалежність від чисельності населення, симетрії (анонімності), принципу трансфертів Пигу-Дальтона, декомпозиції. Індекси Тейла та індекс Аткінсона позбавлені цих недоліків.

Таблиця 1

Показники та методи кількісної оцінки нерівності розвитку просторового капіталу

\begin{tabular}{|c|c|c|}
\hline $\begin{array}{c}\text { Групування за критерієм } \\
\text { класифікації }\end{array}$ & \multicolumn{2}{|c|}{ Показники / методи } \\
\hline $\begin{array}{l}\text { Перша група: показники } \\
\text { масштабу нерівності }\end{array}$ & $\begin{array}{c}\text { Показники } \\
\text { Розсіювання } \\
\\
\text { Коефіцієнт фондів } \\
\text { Децильний коефіцієнт } \\
\text { Індекс Джині } \\
\text { Індекс Гувера } \\
\text { Індекс Тейла } \\
\text { Індекс Аткінсона } \\
\text { Індекс Кольма } \\
\text { Індексі просторової кореляції }\end{array}$ & $\begin{array}{c}\text { Дисперсія } \\
\text { Середнє квадратичне відхилення } \\
\text { Коефіцієнт варіації } \\
\text { Коефіцієнт варіації Вільямсона } \\
\text { Коефіцієнт Клоцвога-Магомедова } \\
\\
\\
\text { Індекс Морана } \\
\text { Індекс Гири }\end{array}$ \\
\hline $\begin{array}{l}\text { Друга група: показники } \\
\text { (методи) які характеризують } \\
\text { структуру нерівності }\end{array}$ & $\begin{array}{c}\text { Локальний індекс просторової } \\
\text { автокореляції } \\
\text { Статистичні характеристики } \\
\text { розподілу } \\
\text { Кластерний аналіз } \\
\text { Індекси Тейла } \\
\text { Індекс Аткінсона }\end{array}$ & $\begin{array}{l}\text { Індекс Гетиса-Одра } \\
\text { Коефіцієнт асиметрії } \\
\text { Коефіцієнт ексцесу }\end{array}$ \\
\hline $\begin{array}{l}\text { Третя група: методи, які } \\
\text { характеризують динаміку } \\
\text { нерівності }\end{array}$ & $\begin{array}{c}\text { Показники } \\
\text { Розсіювання } \\
\\
\text { Індекс Джині } \\
\text { Індекс Гувера (Робін Гуда) } \\
\text { Індекс Тейла } \\
\text { Індекс Аткінсона } \\
\text { Індекс Кольма } \\
\text { Аналіз конвергенції }\end{array}$ & $\begin{array}{c}\text { Дисперсія } \\
\text { Середнє квадратичне відхилення } \\
\text { Коефіцієнт варіації } \\
\text { Коефіцієнт варіації Вільямсона } \\
\text { Коефіцієнт Клоцвога-Магомедова }\end{array}$ \\
\hline
\end{tabular}

Джерело: сформовано автором відповідно до [14, 15, 16] 
Світовий досвід показав, що генераторами і ретрансляторами глобальних змін, осередками якісного розвитку просторового капіталу на певному етапі свого розвитку $\epsilon$ індустріальні центри. Саме тому для оцінки якості просторового капіталу також доцільно використовувати структурний підхід, який дозволяє визначити та порівняти різні зрізи діяльності індустріальних центрів. Удосконалення існуючих підходів та їх адаптація до специфіки розвитку індустріальних центрів дозволили запропонувати п'ять груп показників для оцінки якості просторового капіталу (табл. 2), їх детальний опис опубліковано автором у [21].

Згаданий комплекс показників формує методичну базу до визначення пріоритетних напрямків розвитку індустріальних центрів як прогресивних осередків розвитку просторового капіталу, основними цільовими орієнтирами яких є:

- дестимуляція сировинного експорту та аутсорсингових моделей сервісу та локалізації ланцюжків перероблення сировини;

- диверсифікація економіки та трансформація рентних моделей функціонування індустріального центру;

- обмеження адсорбції морально застарілих технологій та недопущення консервації технологічного відставання;

- забезпечення оптимальної вікової структури кадрового капіталу, у тому числі за рахунок заміни неконкурентних робочих місць технологічним обладнанням; ініціатив.

- заміну патерналістського світогляду та всебічну підтримку підприємницьких

Таблиця 2

Структурні показники оцінки якості просторового капіталу індустріальних центрів

\begin{tabular}{|c|c|}
\hline Групи показників & Показники якості просторового капіталу \\
\hline $\begin{array}{r}\text { I. Показнг } \\
\text { технолог }\end{array}$ & $\begin{array}{l}1.1 \text { Структурні пропорції валового випуску продукції за видами } \\
\text { економічної діяльності } \\
1.2 \text { Структурні пропорції випуску за видами економічної діяльності, } \\
\text { згруповані за типом технологічних укладів }\end{array}$ \\
\hline $\begin{array}{l}\text { II. Показн } \\
\text { (імпортнс }\end{array}$ & $\begin{array}{l}2.1 \text { Структурні пропорції експорту (імпорту) продукції за видами } \\
\text { економічної діяльності }\end{array}$ \\
\hline $\begin{array}{l}\text { III. Показники інтелектуального } \\
\text { капіталу }\end{array}$ & $\begin{array}{l}3.1 \text { Вікова структура зайнятого населення за видами економічної } \\
\text { діяльності } \\
3.2 \text { Структурні пропорції концентрації патентів на винаходи за видами } \\
\text { економічної діяльності } \\
3.3 \text { Співвідношення структурних пропорцій чисельності зайнятого } \\
\text { населення та обсягів виплат заробітної плати за видами економічної } \\
\text { діяльності }\end{array}$ \\
\hline $\begin{aligned} \text { IV. Показ } & \text { інвести }\end{aligned}$ & $\begin{array}{l}4.1 \text { Структурні пропорції обсягів капітальних інвестицій за видами } \\
\text { економічної діяльності } \\
4.2 \text { Структурні пропорції обсягів інвестицій за видами економічної } \\
\text { діяльності }\end{array}$ \\
\hline V. Показники стр & $\begin{array}{l}5.1 \text { Структурні пропорції темпів динаміки обсягів випуску продукції за } \\
\text { видами економічної діяльності }\end{array}$ \\
\hline
\end{tabular}

Сформовано автором

Висновки. Підсумовуючи проведений аналіз підходів до оцінки регуляторних домінант забезпечення сталого економічного розвитку можна констатувати, що категорія «капітал» найчастіше $\epsilon$ центральним інструментом в обгрунтуванні управлінських механізмів розвитку. Проведений аналіз теорій i концепцій, які розкривають природу та методичну сутність капіталу, дозволяють стверджувати про поширеність його досліджень в контексті просторово-економічного підходу. В умовах сьогодення поняття «капітал» використовується для визначення різних видів ресурсів: людський капітал, соціальний капітал, культурний капітал, реляційний капітал i т.п. Зміна управлінської парадигми під впливом розвитку різноманітних форм 
організації простору обумовлює домінування того чи іншого виду капіталу в економічній моделі.

Виявлення векторів зміни ефективних підходів до управління розвитком, як результуючого чинника функціонування капіталу, дозволяє стверджувати, що в умовах трансформації факторної бази локалізації економічної активності одним 3 центральних елементів удосконалення існуючих концептуальних підходів до управління розвитком $\epsilon$ подолання протиріч між мережевою та просторовою складовою.

Управління мережевими формами організації простору ускладнюється та, у свою чергу, зменшує дієвість існуючих концептуальних підходів. Процеси економічної інтеграції, зменшення ролі кордонів країн, транснаціоналізація зумовлюють зростання складності управлінських систем. Пошук відповіді на таке зростання складності полягає у визначенні горизонтів охоплення мережі з метою реалізації управлінських впливів. Такими горизонтами зазвичай виступає громада, регіон, країна або галузь, сектор і т.п. залежно від форми організації простору.

Ключовим параметром оцінки якості простору є оцінка його нерівномірності, як характеристика відцентрованого та дезінтегруючого тяжіння елементів мережі. Існує широкий спектр підходів до оцінки нерівномірності просторового капіталу, однак найчастіше використовуються спеціальні індикатори диференціації та поляризації за рівнем розвитку. Серед всього різноманіття підходів найбільш прийнятними $є$ індекси Тейла, індекс Аткінсона, які дозволяють виявити масштаб, динаміку та структуру нерівномірності розвитку просторового капіталу за кожною компонентою.

Індикаторами ступеня взаємодії центрів формування мережі та їх інтеграції у глобальні ланцюги створення доданої вартості виступають структурні показники, ефективність яких доводять не тільки результати досліджень провідних науковців та експертів, але й практичний досвід застосування. Зокрема, при реалізації стратегічного плану розвитку Європейського Союзу «Європа-2020» на засадах соціальної згуртованості та смарт спеціалізації.

\section{Список бібліографічного опису:}

1. Ukraine-Systematic Country Diagnostic: toward sustainable recovery and shared prosperity. 2017. Washington, DC: The World Bank. Режим доступу : http://documents.worldbank.org/curated/en/268021494851394908/pdf/Ukraine-SCD-Document-April28-201705102017.pdf.

2. Smith A. The Wealth of Nations: An Inquiry into the nature and Causes of the Wealth of Nations. New York, 2003 (first published in 1776 ). $754 \mathrm{p}$.

3. Capello R. Location, Regional Growth and Local Development Theories. Aestimum. 2011. Vol. 58. P. 1-25.

4. Przygodzki Z. Kapitał terytorialny w rozwoju regionów. Acta Universitatis Lodziensis. 2016. Vol 2. P. $83-97$.

5. Pike A., Rodriguez-Pose. A., Tomaney J. What kind of local and regional development and for whom? Regional Studies. 2007. Vol. 41. P. $1253-1269$.

6. Hudson W. Intellectual capital: How to build it, enhance it, use it. New York, 1993. 239 p.

7.Zaucha J., Brodzicki T., Ciołek D. and other. Terytorialny wymiar wzrostu i rozwoju. Warsaw, $2015.320 \mathrm{p}$

8. Wojnar K. Ocena oddziaływania na terytorium jako instrument polityki przestrzennej. Terytorialny wymiar rozwoju. Polska z perspektywy badań ESPON. 2013. P. 12-30.

9.Territorial Outlook. Territorial Economy. Paris, 2001. $\quad$ Режим доступу http://www.vwl.tuwien.ac.at/hanappi/AgeSo/SecReps/Territorial_Outlook_F.pdf.

10. Cohen S. B. Geography and Politics in Divided World. London, 1994. 384 p.

11. Мезенцев К., Олійник Я., Мезенцева Н. Урбаністична Украӥна: в епіцентрі просторових змін. Київ, 2017.438 с.

12. Krugman P. First Nature, Second Nature, and Metropolitan Location. Journal of Regional Science. 1993. Vol. 33. P. $129-144$.

13. Батанов О. В. Територіальна громада - первинний суб'єкт муніципальної влади в Україні: поняття та ознаки. Вісник Центральної виборчої комісії. 2008. № 2 (12). С. 51-57.

14. ESPON SIESTA - Spatial Indicators for a Europe 2020 Strategy Territorial Analysis. ESPON. 2012. Режим доступу : https://www.espon.eu/programme/projects/espon-2013/applied-research/siesta-spatial-indicatorseurope-2020-strategy.

15. Guidance for Member States on Integrated Sustainable Urban Development. European Сommission. 2016. Режим доступу : http://ec.europa.eu/regional_policy/sources/docgener/informat/2014/guidance_sustainable_urban_dev elopment_en.pdf.

16. Medeiros E. Territorial Impact Assessment (TIA): The Process, Methods, Тесhniques. 2014. Режим доступу https://infoeuropa.eurocid.pt/files/database/000065001-000066000/000065239.pdf.

17. Theil H. Economics and information theory. Amsterdam, 1967. 488 p.

18. Atkinson A.B. On the Measurement of Inequality. Journal of Economic Theory. 1970. 2(3). P. $244-263$.

19. Williamson J.G. Regional inequality and the process of national development: A description of patterns. Economic Development and Cultural Change. 1965. №13. P. 3-45.

20. Клоцвог Ф.Н., Магомедов Г.М. Пути активизации российской региональной политики. Научные труды: Институт народнохозяйственного прогнозирования РАН. 2005. С. 81-91. 
21. Rodchenko V., Jiafei Guo, Prus Yu., and Liu Zeyu. Criteria for choosing the priorities of a smart development of industrial centers in the context of globalization. International Transport Infrastructure, Industrial Centers and Corporate Logistics (NTI-UkrSURT 2019) : Fifteenth Scientific and Practical International Conference. SHS Web of Conferences. Volume 67, 2019. DOI https://doi.org/10.1051/shsconf/20196701012.

\section{References:}

1. Ukraine-Systematic Country Diagnostic: toward sustainable recovery and shared prosperity. 2017. Washington, DC: The World Bank. URL : http://documents.worldbank.org/curated/en/268021494851394908/pdf/Ukraine-SCD-Document-April28-2017-05102017.pdf [in English].

2. Smith, A. (2003). The Wealth of Nations: An Inquiry into the nature and Causes of the Wealth of Nations. New York: Bantam Classics [in English].

3. Capello, R. (2011). Location, Regional Growth and Local Development Theories. Aestimum, 58, 1-25 [in English].

4. Przygodzki, Z. (2016). Kapitał terytorialny w rozwoju regionów. Acta Universitatis Lodziensis, 2, 83-97 [in Polish].

5.Pike, A., Rodriguez-Pose, A., Tomaney, J. (2007). What kind of local and regional development and for whom? Regional Studies, 41, 1253-1269 [in Polish].

6. Hudson, W. (1993). Intellectual capital: How to build it, enhance it, use it. New York: John Wiley \& Sons [in English].

7. Zaucha, J., Brodzicki, T., Ciołek, D. and other (2015). Terytorialny wymiar wzrostu i rozwoju. Warsaw: Difin [in Polish].

8. Wojnar, K. (2013). Ocena oddziaływania na terytorium jako instrument polityki przestrzennej. Terytorialny wymiar rozwoju. Polska z perspektywy badań ESPON [in Polish].

9.Territorial Outlook. Territorial Economy $\quad$ (2001). Paris $\quad$ : http://www.vwl.tuwien.ac.at/hanappi/AgeSo/SecReps/Territorial_Outlook_F.pdf [in English]

10. Cohen, S. B. (1994). Geography and Politics in Divided World. London [in English].

11. Mezentsev, K., Oliynyl, Ya., \&, Mezentseva, N. (2017). Urbanistychna Ukraina: v epatsentri prostorovykh zmin [Urban Ukraine: At the Epicenter of Spatial Change]. Kyiv : Feniks [in Ukrainian].

12. Krugman, P. (1993). First Nature, Second Nature, and Metropolitan Location. Journal of Regional Science, 33, 129-144 [in English].

13. Batalov, O. (2008). Terytorialna gromada - pervynnyi subekt munitsypalnoi vlady v Ukraini: poniattia ta oznaky [Territorial community - the primary subject of municipal government in Ukraine: concepts and features]. Visnyk Tsentralnoi vyborchoi komisii - Bulletin of the Central Election Commission, 2(12), 51-57 [in Ukrainian]

14. ESPON SIESTA - Spatial Indicators for a Europe 2020 Strategy Territorial Analysis. (2012). ESPON. URL : https://www.espon.eu/programme/projects/espon-2013/applied-research/siesta-spatial-indicatorseurope-2020-strategy [in English].

15. Guidance for Member States on Integrated Sustainable Urban Development. European Commission. 2016. URL : http://ec.europa.eu/regional_policy/sources/docgener/informat/2014/guidance_sustainable_urban_dev elopment_en.pdf [in English].

16. Medeiros E. (2014). Territorial Impact Assessment (TIA): The Process, Methods, Techniques. URL : https://infoeuropa.eurocid.pt/files/database/000065001-000066000/000065239.pdf [in English].

17. Theil, H. (1967). Economics and information theory. Amsterdam : North-Holland [in English].

18. Atkinson, A.B. (1970). On the Measurement of Inequality. Journal of Economic Theory, 2(3), 244-263 [in English].

19. Williamson, J.G. (1965). Regional inequality and the process of national development: A description of patterns. Economic Development and Cultural Change, 13, 3-45 [in English].

20. Klotsvog, F.N, \&, Magomedov, G.M. (2005). Puti aktivizatsii rossiyskoy regionalnoy politiki [Ways to step up Russian regional policy]. Nauchnye Trudy: Institut narodnokhoziaystvennogo prognozirovaniia RAS - Scientific works: Institute of Economic Forecasting RAS, 81-91 [in Russian].

21. Rodchenko, V., Jiafei Guo, Prus, Yu., \&, Liu Zeyu (2019). Criteria for choosing the priorities of a smart development of industrial centers in the context of globalization. International Transport Infrastructure, Industrial Centers and Corporate Logistics (NTI-UkrSURT 2019) : Fifteenth Scientific and Practical International Conference. SHS Web of Conferences, 67. DOI https://doi.org/10.1051/shsconf/20196701012 [in English].

\section{Дата подання публікації 04.04.2020 p.}

